\title{
Current Situation of PC12 Cell Use in Neuronal Injury Study
}

\author{
Wei-Li Wang ${ }^{1}$, Rong Dai ${ }^{1}$, Han-Wen Yan ${ }^{1}$, Chun-Ni Han ${ }^{1,2}$, Li-Song Liu ${ }^{1}$ and Xiao-Hua \\ Duan $^{2, *}$
}

${ }^{1}$ The State Administration of Traditional Chinese Medicine Traditional Chinese Medicine Scientific Research Level Three Laboratory-Chinese Medicine Pharmacology Laboratory, at Yunnan Province, Yunnan University of Traditional Chinese Medicine, Kunming 650500, Yunnan Province, China

${ }^{2}$ The Key Modern Research Laboratory for Ethno-pharmacology of Yunnan Higher School at Yunnan Province, Yunnan University of Traditional Chinese Medicine, Kunming 650500, Yunnan Province, China

\begin{abstract}
The nervous system diseases are easy to get and hard to cure. The mechanism is bound up with nervous cells injure, so it's significant to study medicine protect nervous cells injure. We need find an ideal model to study these diseases. PC12 cell is a pheochromocytoma cell line from RattusNorvegicus, because it has some characters of nerve cells and easy to cultivate and passage, these cells have been proved to be a useful cell model to study nervous physiology and pharmacology. There are several of PC12 cells, American type culture collection supply two kinds of PC12 cell named PC12 cell and PC12Adh. There are high differentiation, low differentiation and undifferentiating in domestic. Although they are very similar, there are still some differences, and not every PC12 cell is effective for every experimental model. After compared, we hold that PC12Adh cell line is more suitable for neurite outgrowth studies under ROCK inhibitor than the PC12 cell line, PC12 cells that induced by NGF and high differentiated PC12 cell are similar to cerebral cortical neurons, they are suitable for various physiological and pathological study of nervous system. Undifferentiated PC12 cells due to low levels of dopamine, therefore it is not suitable for study on neural cells.
\end{abstract}

Keywords: Nerve cells, PC12 Cell, Cell differentiation, Neural injury.

\section{INTRODUCTION}

The nervous system diseases like Parkinson syndrome, senile dementia, Alzheimer's disease, Ischemic cerebral vascular disease and so on are easy to get and hard to cure. The mechanism is bound up with nervous cells injure, so it's significant to study medicine protect nervous cells injure. At present some researchers use cortex nerve cells as a model for studying nerve damage. However, neurons isolated from mature nerve tissues will be hurt. Therefore, the structure and function research of neural system mostly use primary culture of fetal rat's neurons [1]. Although the primary culture of fetal rat's neurons of neurons in high purity, show a higher activity, more representative of the development and physiological activity of neurons in vivo [2], however, it is time consuming, high cost, hard to get and cultivate [3]. Thus, it is very important to find a kind of immortalized cell which is similar to primary culture of fetal rat's neurons and easy to cultivate and develop in vitro.

PC12 cell is a pheochromocytoma cell line from Rattusnorvegicus, is a kind of catecholamine cells, and it can synthesis, storage and release moderate dopamine and norepinephrine. After incubated with

*Address correspondence to this author at the Key Modern Research Laboratory for Ethno-pharmacology of Yunnan Higher School at Yunnan Province, Yunnan University of Traditional Chinese Medicine, Kunming 650500, Yunnan Province, China; Tel: +8615887815413;

Fax: +86087165919481; E-mail: 1047896527@qq.com, 191045876@qq.com nerve growth factor, the morphological pattern, physiology and biochemistry of PC12 cell differentiate into parasympathetic orpremotor neuron, and it represents the function of neuron. Because it easy to cultivate and passage, so after induced it is an in common use tool in nervous system in vitro [4]. Nevertheless, there are many kinds of PC12 cells. American type culture collection (ATCC) offers PC12 cell and PC12Adh. In domestic, we can purchase high differentiation, low differentiation and undifferentiating. Although much of the cells are used in experimental models, but for the further study of these cells have not been reported. In some study, researcher found that not every PC12 cell is effective for every experimental model. This paper aim to sum up usual use PC12 cells, describe their morphological pattern, physiology and use to give some advice how to choose different kinds of PC12 cells reasonably.

\section{THE PC12 CELLOF AMERICAN TYPE CULTURE COLLECTION}

ATCC offers two kinds of PC12 cells named PC12 cell (CRL-1721 ${ }^{\mathrm{TM}}$ ) [5] and PC12Adh (CRL1721. $1^{\mathrm{TM}}$ ) [6]. ATCC offer PC12 cell only before July 2006 , this cell line described the mixture of PC12 cell and PC12Adh now. After January 2009, ATCC amend the information of PC12 cell recorded, and add a PC12Adh cell line to record. These two pheochromocytoma cell lines from Rattusnorvegicus can use for transfecting host. They cannot synthesize 
Table 1: The Difference between PC12 Cell and PC12Adh

\begin{tabular}{|c|c|c|}
\hline & PC12 & PC12Adh \\
\hline \hline growth characterization & Cluster of floating cells & Adherence, small drusy \\
\hline morphology & Small and irregular & polygonal \\
\hline Cell culture & $\begin{array}{c}\text { PC12 cells were incubated in RPMI-1640medium with } \\
10 \% \text { heat-inactivated horse serum and } 5 \% \text { fetal bovine } \\
\text { serum inan atmosphere containing } 5 \% \text { carbon dioxide } \\
\left(\mathrm{CO}_{2}\right) \text { and95\% air at } 37^{\circ} \mathrm{C} .\end{array}$ & $\begin{array}{c}\text { PC12Adh cells were incubated in Hams } \mathrm{F} 12 \mathrm{~K} \\
\text { medium with } 15 \% \text { horse serum and } 2.5 \% \text { fetal } \\
\text { bovine serum in an atmosphere containing } \\
5 \% \mathrm{CO}_{2} \text { and } 95 \% \text { air at } 37^{\circ} \mathrm{C}\end{array}$ \\
\hline Rho kinase (ROCK) & Non sensitive & sensitive \\
\hline Preservation & $10 \% \mathrm{DMSO}$ & $5 \% \mathrm{DMSO}$ \\
\hline
\end{tabular}

epinephrine, can secrete catecholamine, but there morphology and growth situation and so on are different [5-7] (Table 1).

Because PC12 cell has some similar characteristics of nerve cells, they are widely used in various physiological and pathological studies of nervous system at home and abroad, such as neurotoxicity and nerve cells apoptosis [8]. However, few data are available about PC12Adh research and the nerve cell differentiation $[9,10]$.Other studies found that ROCK inhibitor induced PC12Adh neurite outgrowth, but had little impact on PC12 cell, because tolerance is a result of gene expression regulation, and it could be stronger following longer exposure to ROCK inhibitors [11,12]. Thus, PC12Adh cell line is more suitable for neurite outgrowth studies under ROCK inhibitor than the PC12 cell line, and the mechanism could be associated with up-regulation of inflammatory pathways and downregulation of cell cycle pathways [13]. There is research point out dehydroepiandrosterone-sulphate (DHEA-S) promoted PC12 cell differentiation [14]. Studying the $G$ protein mediated signal of cocaineamphetamine regulated transcript (CART) peptide stimulation by differentiated PC12 cell, determined PACAP (6-38) as function of one of the CART receptor antagonists, CART participate in various physiological reactions, and it's nerve conduction peptide and hormone [15].

\section{PC12 CELL SUPPLIED BY TYPE CULTURE COLLECTION OFTHECHINESE ACADEMYOF SCIENCES, SHANGHAI, CHINA}

According to Type Culture Collection of the Chinese Academy of Sciences, Shanghai, China, (published in 2012), there are three kinds of PC12 cells: high differentiation, middle differentiation, and low differentiation. They are different in their morphological and physiological features. The sources of these cells are the same with the two of ATCC supply. The PC12 cell of ATCC is undifferentiated cell. However, high differentiation cell nerve outgrowth is longer, and more similar to neural cells.

\subsection{Undifferentiated PC12 Cell}

\subsubsection{The Characteristics of Undifferentiated PC12 Cell}

Majority of studying report that the morphology of undifferentiated PC12 cell are roundness, scattered shape growth or poly group growth [16-18], but there are also some research said the morphology of undifferentiated $\mathrm{PC} 12$ cell are roundness, polygon, fusiformis $[19,20]$, they do not have nerve outgrowth. Type Culture Collection of the Chinese Academy of Sciences, Shanghai, China, describe it is polygon. We can see undifferentiated $\mathrm{PC} 12$ cell as immaturate neuron, tyrosine hydroxylase, dopamine beta hydroxylase, dopamine decarboxylase, monoamine oxidase, catechol methyltransferase and so on are low in cell, the cell show a low responsiveness to sympathetic transmitter. But it express some characteristics of neuron include: synthetize, store, and secretion of noradrenalin(NA) and dopamine (DA) to respond the concentration of outside cell potassium ion, the active rise of nicotinic acetylcholine receptor and existence of acetylcholin esterase (AChE), gamma-aminobutyric acid(GABA) and tyrosine hydroxylase. Undifferentiated PC12 cell deal with glucocorticoid like DXM can induce differentiate into characteristic of strong response to calcium ion, and up-regulation synthetize and store of catecholamine enzyme, especially DA, increase activity of tyrosine hydroxylase and reduce activity of choline acetyltransferase [21].

\subsubsection{The Use of Undifferentiated PC12 Cell}

Several of growth factor, neurotrophin, and hormone promote biological effect of differentiation, 
proliferation, and survival of undifferentiated PC12 cell, is primary cell model of studying nerve cell differentiation in vitro [19]. As one of the neurotrophin, nerve growth factor found at the earliest, and the most thorough. Nerve growth factor is a nerve cell growth regulatory factor, and it is a nerve cell grow regulatory factor has double biology function feature of nutrition and promote outgrowth grow, it has significant regulating effect to growth, differentiation, regeneration, and express of functional performance of central and peripheral neuron. Nerve growth factor can induce nerve fiber orientated growth in puberty, stimulate the growth of soma and dendritic, increase the density of dominated area nerve fibers, promote differentiation and growth of neuron, increase sensory nerve and sympathetic ganglion, increase in volume, extend the fiber; the level and distribution of NGF and NGF receptor are obvious reduced, the dependence of main effect of nerve to NGF is also significantly lower, only part of the sympathetic neurons still need to rely on NGF survival. It is best to use undifferentiated cells when use NGF induce PC12 cell. After induced by NGF PC12 cells grew, and sensitivity to neurotransmitter and electricity [22]. Some research indicate PC12 induced by NGF 4 14d, cell volume increases, neurite grow, form net, A few weeks later, neurite is 500 1000Lm[23], and cells stopped proliferation. It can use for studying secretion and uptake of nutrients. PC12 cell induced by NGF has the characteristics of sympathetic neurons. For example, NGF induced PC12 cell enhances the acetylcholine synthesizing capacity and thus increase the activity of acetylcholine [24]. Nowadays, most of the research of points out that NGF induces PC12 cell differentiation resulting neuron belonging to the differentiated cells, there is no division ability, and induced PC12 cell differentiation is reversible, therefore PC12 cell as neuron must first by induction, the induced cells cannot use for research after many times passages [25,26]. But there are reports of differences, in 2005, LU Shuang-Hong et al. first observed PC12 cells still retain the ability to differentiation after induced, and found after induced by NGF, there is DNA in cells, except soma fission, the neurite outside soma can also one divides into two [27]. In addition, there is distribution of a wide range of delayed rectifier potassium channel in undifferentiated PC12 cell, only a few cells expression of transient outward potassium channel [28]. But there is research indicated undifferentiated PC12 cell as cell model need inducer, and it's cumbersome, So according to the experimental characteristics to choose the appropriate degree of differentiation cells as experimental model [29].

\subsubsection{Compare Undifferentiated PC12 Cells and Cortical Neurons}

The differences between two kinds of cells, there are several ways: first, cortical neurons have multiple neurites is an important structure of the neurons that transmit information, and undifferentiating PC12 cell have no neurites, so they have big difference on morphology. Second, they have difference on sensitivity to neurotransmitter, cortical neurons secrete lots of neurotransmitters, and undifferentiated PC12 cell respond to the neurotransmitter is weak. Third, they have big difference on electrochemical capacity, nerve cell electrochemical capacity more obvious, and transmembrane transport though membrane potential, there are a lot of sodium and potassium ion channels on the membrane, but undifferentiated PC12 cell only distribution of delayed rectifier potassium channel; Fourth, mature nerve cells are not proliferating, but undifferentiated PC12 cell can survival after passage.

\subsection{High Differentiated PC12 Cell}

\subsubsection{The Characteristic of High Differentiated PC12 Cell}

High differentiation of PC12 cells contains a lot of dopamine receptor and various enzymes required for the decomposition and synthesis of dopamine, similar to the cortical neurons. It's neuronal precursor cells line with differentiation potential and sympathetic neurons characteristics. PC12 cells mainly directly to the cell bank to buy. Cell Bank, Chinese Academy of Sciences described as a polygon. Direct purchase of high differentiation of PC12 cell morphology is fusiform mainly, there are neurites, and the cells proliferated quickly, high degree of purification, short culture period, and convenient use and are easy to control. High differentiated PC12 cell can't synthesize epinephrine [30].

\subsubsection{The Use of High Differentiated PC12 Cell}

PC12 cell not only morphology, but also many aspects such as physiology and biochemistry are similar to bovine chromaffin cells under usual cultivate condition. High differentiated PC12 cell in physiology and physiology are more similar to dopaminergic neurons of midbrain, it can synthesis, storage and release moderate catecholamine, norepinephrine and so on. High differentiated PC12 cell usually as 
Table 2: Comparison of High Differentiated PC12 Cell, PC12 Cell Induced by NGF, and Cortical Neurons

\begin{tabular}{|c|c|c|c|}
\hline & Cortical neurons & PC12 cell induced by NGF & High differentiated PC12 \\
\hline \hline Morphology & Irregular, many neurites & Irregular, many neurites & Fusiform, stuntedneurites \\
\hline Neurotransmitter & Secrete neurotransmitters & Secrete neurotransmitters & Secrete neurotransmitters \\
\hline Electrochemical capacity & $\begin{array}{c}\text { Presence of Na+, K+ ion } \\
\text { channel, pass signal }\end{array}$ & Presence of Na+, K+ ion channel & Rapid proliferation \\
\hline Proliferation & $\begin{array}{c}\text { Mature neurons cannot } \\
\text { proliferate }\end{array}$ & $\begin{array}{c}\text { After induced differentiation of } \\
\text { PC12 cells, theycannot proliferate }\end{array}$ & \\
\hline
\end{tabular}

dopamine cell model abroad, an ideal cell model to study a variety of poison effect on dopamine neurons in vitro [31].

Now are more used for mechanism and cell protective effect research of diseases of nervous system such as Parkinson syndrome, senile dementia, Alzheimer's disease, ischemic cerebrovascular disease and amyotrophic lateral sclerosis, is one of the cell model study physiology, pathology and pharmacology of nerve cell differentiation [6, 32]. For example, the mechanism of Parkinson syndrome is concerned with dihydroxyphenylalanine reduce of striatum. At present the more accepted theory for the dopamine theory and Oxidative stress theory [33]. In the experiment, commonly used rotenone damage cells, simulate relevant pathological process of Parkinson's disease to studying relevant mechanism and nerve protective effect [34]. Thus, further illustrate undifferentiated PC12 cells due to low levels of dopamine, so it is not suitable for study on neural cells.

\subsection{Low Differentiated PC12 Cell}

Low differentiated PC12 cells are polygonal, loose and adherent, pluricellular aggregation, and cell cannot synthetic adrenaline. There are also the literature with low differentiated PC12 cells do nerve cells differentiation related research, Low differentiated PC12 cells in the classical pathway of Ras /Raf/ MEK / ERK, NGF can stimulate PC12 cells to differentiate into neurons which have effect of sympathetic nerve cells $[16,35]$. Low differentiated PC12 cells can grow without special inducer, such as the use of nerve growth factor induce PC12 cells into neuron-like cell. However, in the process of passage the differentiation degree increase gradually, gradually appear neuron-like cells, is advantageous to studying neurites growth. For example, Li Li-hua use low differentiated PC12 cell as object of Parkinson syndrome's model [29], and Kong Song-zhi use for studying Alzheimer's disease [36].
Low differentiated PC12 cell commonly used for cell model of simulating neurons apoptosis [8].

\section{CONCLUSION}

PC12 cells are used to all kinds of nerve tests, but it is not sensitive to ROCK, and PC12Adh is sensitive to ROCK, thus, PC12Adh is better to ROCK test than PC12 cells. At the same time, ROCK inhibitor just induces the long protrusions of PC12Adh cells, and has not any effect to PC12 cells. Undifferentiated PC12 cells are weak to the neurotransmitter reaction of sympathetic nerve, after induction differentiation, the sensitivity of PC12 cells to acetylcholine higher than before. PC12 cells that induced by NGF is more similar to cerebral cortical neurons, there are many potassium channels on the surface membranes of PC12 cells and the potassium channels have electrical excitability. Undifferentiated PC12cells just have a small amount of transient outward potassium current. The induced cells have stopped differentiating so as to they are similar to nerve cell so only induced PC12cells could replace nerve cell. There are many fairly similarities between high differentiation PC12 cells and the midbrain dopamine neurons on shape, physiology and biochemical function and so on. They are excitable, they can secretion Catecholamine neurotransmitter that include dopamine, norepinephrine. Therefore, PC12cells become ideal cell model to study multiple poison which act on dopaminergic neuron. The low differentiated PC12 cells do not need induce a lot specially, such as the use of nerve growth factor induce PC12 cells into neuron-like cell. This because in the process of passage, the differentiation degree increase gradually, with gradual development of neuron-like cells which give advantageous to studying neurite.

When applying all kinds of PC12 cells, attention should be paid to that the number of passage is limited. After many times passages, the cells biological characteristics may be changed. Thus, recovering new 
cells is necessary in order to ensure the cell line quality. Special attention should be paid to observation the cell morphology when using undifferentiated and low differentiated PC12 cells. Any changes in morphology indicate the initiation of differentiation process.

\section{ACKNOWLEDGEMENTS}

The work was supported by the project of Natural Science Foundation of China (81160514), Scientific Research Fund project of Yunnan Education Department (2014Z120), and Applied basic research plan on the project in Yunnan province (2014FB153). We thank Associate Prof. Ms. Qing Lin for the helpful discussions and abstract. We are in debt to teacher Ms. XiaohuaDuan for the help on cell knowledge.

\section{REFERENCES}

[1] Song HY, Wang ZY, Li NN. Primary cultivation and identification of cortical neuron in neonatal rats. J Appl Clin Pediatr 2012; 27: 129-31.

http://dx.doi.org/10.3969/j.issn.1003-515X.2012.02.022

[2] Li CL, Yang BF, Zhang JH, Jiao JD, Huang WS, Wu CF. Primary culture method and identify in neonatal rat hippocampal and cortical neurons. J of Journal of Shenyang Pharm Aceutical University. 2011; 4: 299-304. http://www.cnki.net/KCMS/detail/detail.aspx?QueryID=1\&Cur Rec=3\&recid=\&filename=SYYD201104015\&dbname=CJFD2 011\&dbcode $=$ CJFQ\&pr $=\&$ urlid $=\& y x=\& v=M D Y 4 N j g 3 R G g x V D$ NxVHJXTTFGckNVUkwrZIIIUm9GeUhrVjdyQk5qVFNhckc0S DIETXE0OUVZWVI4ZVgXTHV4WVM=

[3] Qi XM. The protective effects of valproate on cell model of Parkinson's disease. Master Thesis, Suzhou University, Jiangsu, China 2014; 3-18. http://d.wanfangdata.com.cn/ Thesis_D506661.aspx

[4] Greene LA, Tischler AS. Establishment of a noradrenergic clonal line of rat adrenal pheochromocytoma cells which respond to nerve growth factor. Proc Nat Acad Sci USA 1976; 73: 2424-8.

http://dx.doi.org/10.1073/pnas.73.7.2424

[5] ATCC. CRL-1721product details [EB/OL]. [updated 2015 June 27]. http://www.atcc.org/Products/All/CRL-1721. aspx?geo_country=cn\#generalinformation

[6] ATCC. CRL-1721.1productdetails [EB/OL]. [updated 2015 June 27]; http://www.atcc.org/Products/All/CRL1721.1.aspx\#generalinformation

[7] Que L, Duan WG, Zhang LY, Jiang ZZ. Differences of neurite outgrowth induced by rho kinase inhibitors between in PC12 cell line and PC12Adh cell line. J of Yunnan Univ (Natural Sciences) 2011; 33: 370-2. http://www.cnki.net/KCMS/ detail/detail.aspx?Query|D=0\&CurRec=1\&recid=\&filename= YNDZ201103024\&dbname=CJFD2011\&dbcode=CJFQ\&pr= \&urlid=\&yx=\&v=MDM1NDhIOURNckk5SFIJUjhIWDFMdXhZ UzdEaDFUM3FUcldNMUZyQ1VSTCtmWWVSb0Z5L2tXNzN KUENQUGRMRZQ=

[8] Liu XY. Ghrelin inhibits high glucose-induced PC12 cells apoptosis and its molecular mechanisms. Master Thesis, Chongqing Medical Univ, Chongqing, China 2014; 38-42. http://d.wanfangdata.com.cn/Thesis_Y2689258.aspx

[9] Terzi YK, Kocaefe YC, Ayter S, Kocaefe, Ayter S. Coronin 1A inhibits neurite outgrowth in PC12 cells. J Neurosci Lett 2014; 582: 38-42.

http://dx.doi.org/10.1016/j.neulet.2014.08.044
[10] Tamplenizza M, Lenardi C, Maffioli E, et al. Nitric oxide synthase mediates $\mathrm{PC} 12$ differentiation induced by the surface topography of nanostructured TiO2. J Nanobiotechnol 2013; 11: 35.

http://dx.doi.org/10.1186/1477-3155-11-35

[11] Phan CW, Wong WL, David P, Naidu M, Sabaratnam V. Pleurotusgiganteus (Berk.) Karunarathna \& K. D. Hyde: Nutritional value and in vitro neurite outgrowth activity in rat pheochromocytoma cells. J BMC Complement Altern Med 2012; 12: 102.

http://dx.doi.org/10.1186/1472-6882-12-102

[12] Duan W, Que L, Lv X, Li Q, Yin H, Zhang L. Tolerance of neurite outgrowth to Rho kinase inhibitors decreased by cyclooxygenase-2 inhibitor. J NeurRegen Res 2012; 7: 270512.

http://dx.doi.org/10.3969/j.issn.1673-5374.2012.34.008

[13] Yin H, Hou X, Tao T, Lv X, Zhang L, Duan W. Neurite outgrowth resistance to rho kinase inhibitors in PC12Adh cell. J Cell Biollnternat 2015; 1-14. http://dx.doi.org/10.1002/cbin.10423

[14] Krug AW, Langbein H, Ziegler CG, Bornstein SR, Eisenhofer G, Ehrhart-Bornstein M. Dehydroepiandrosterone-sulphate (DHEA-S) promotes neuroendocrine differentiation of chromaffin pheochromocytoma PC12 cells. J Molec Cell Endocrinol 2009; 300: 126-31.

http://dx.doi.org/10.1016/j.mce.2008.10.026

[15] Lin YM, Hall RA, Kuhar MJ. CART peptide stimulation of G protein-mediated signaling in differentiated PC12 Cells: Identification of PACAP 6-38 as a CART receptor antagonist. J Neuropeptides 2011; 45: 351-8. http://dx.doi.org/10.1016/j.npep.2011.07.006

[16] Wang GQ. Proteomics of the differentiation of PC12 cells and Cos-7 stable cell line express TrkA under the stimulation of nerve growth factor and protective effect of melatonin on dopaminegic neurons. Doctoral Dissertation, the Second Military Medical Univ, Shanghai, China 2003; 10-37. http://dx.doi.org/10.7666/d.y557298

[17] Zhao WJ, Wei L, He JH, Yang YM. Evaluation of the controlled release of NGF from genipin-crosslinked chitosan membranes immobilized with NGF. Med J Comm 2010; 24: 220-2.

http://dx.doi.org/10.3969/j.issn.1006-2440.2010.03.002

[18] Meng L, Jiang A, Chen R, et al. Inhibitory effects of multiwall carbonnanotubes with high iron impurity on viability and neuronal differentiation in cultured PC12 cells. J Toxicol 2012; 313: 49-58.

http://dx.doi.org/10.1016/j.tox.2012.11.011

[19] Wang XL, Chen D, Liu JM. Differentiation of PC12 cells into neurons induced by NGF. J of Jilin University (Medicine Edition), Jilin, China 2007; 33: 827-30.

http://dx.doi.org/10.3969/j.issn.1671-587X.2007.05.013

[20] Zhang W, Zhang BF, Pen FF, Wu CD. PC12 cells neuron differentiation induced by NGF. J of Jianghan University (Natural Sciences) 2008; 36: 68-72. http://dx.doi.org/10.3969/j.issn.1673-0143.2008.03.021

[21] Jiang H. Mechanism Study of Colistin Sulfate Induced Apposite in PC12 Cells. Northeast Agricultural University. Doctoral Dissertation, HeiLongjiang, China 2013; 111. http://www.cnki.net/kcms/detail/detail.aspx?filename $=101320$ 7789. nh\&dbcode $=$ CDFD\&dbname $=$ CDFD2013\&v

[22] Shi LJ, Wang K, Liu LA, Wang CA. The properties and sensitivity to acetylcholine of PC12 cells differentiated with NGF. Chin J Appl Physiol 2003; 19: 74-7. http://dx.doi.org/10.3969/j.issn.1000-6834.2003.01.018

[23] Yang $X$, Liu $X$, Zhang $X$, Lu H, Zhang J, Zhang $Y$. Investigation of morphological and functional changes during neuronal differentiation of PC12 cells by combined Hopping Probe Ion Conductance Microscopy and patch-clamp technique. J Ultramicroscopy 2011; 111: 1417-22. http://dx.doi.org/10.1016/j.ultramic.2011.05.008 
[24] El Omri A, Han J, Yamada P, Kawada K, Ben Abdrabbah M, Isoda H. Rosmarinus officinalis polyphenols activate cholinergic activities in PC12 cells through phosphorylation of ERK1/2. J Ethnopharmacol 2010; 131: 451-8. http://dx.doi.org/10.1016/j.jep.2010.07.006

[25] van Grunsven LA, Thomas A, Urdiales JL, et al. Nerve growth factor-induced accumulation of $\mathrm{PC} 12$ cells expressing cyclin D1: evidence for a G phase block. J Oncogene1996; 12: 855-62. http://www.ncbi.nlm.nih.gov/pubmed/?term= 8632908

[26] Rudkin BB, Lazarovici P, Levi BZ, Abe Y, Fujita K, Guroff G. Cell cycle-specific action of nerve growth factor in PC12 cells: differentiation without proliferation. EMBO J 1989; 8: 3319-25. 2555160

[27] Lv SH, Yang Y, Liu SJ. An investigation on the division of neuronal PC12 cells induced by nerve growth factor. $J$ of Sheng Li Xue Bao, 2005; 57: 552-6. http://www.ncbi.nlm. nih.gov/pubmed/16220192

[28] Zhou H, Wang XJ, Weng ZJ, Ma J, Li JQ. Inhibition of (1R, 2R)-SIPI5358 and SIPI5358 on delayed rectifier potassium current in undifferentiated PC12 Cells. Chin J Pharmaceut 2012; 43: 443-7.

http://dx.doi.org/10.3969/j.issn.1001-8255.2012.06.013

[29] Li LH. Directly Induction of bone mesenchymal stem cells to neuron-like cells and preparation of the cell models of Parkinson's disease. Master Thesis, Yangzhou Univ, Jiangsu, China 2014; 35. http://d.wanfangdata.com.cn/ Thesis_Y2632257.aspx

[30] Wen JL. The study of the protective effect of phenols of Gastrodiaelata Blume on oxidative damage of PC12 cells induced by $\mathrm{H}_{2} \mathrm{O}_{2}$. Master Thesis, Yunnan Univ of Traditional Chinese Medicine 2013; 21. http://d.wanfangdata.com.cn/ Thesis_Y2400584.aspx
[31] Cao R. Role of a-synuclein-tau interaction in manganeseinduced neurotoxicity and protective effect of genistein. Doctoral Dissertation, the Fourth Military Medical University, Xi'an, China 2013; 42.

\section{http://dx.doi.org/10.7666/d.D357289}

[32] Chen X. ALS-associated mutations of protein SOD1-G93A induced injury in PC12 cell. Master Thesis, Hebei Medical University, Hebei, China 2014; 10. http://d.wanfangdata. com.cn/Thesis_Y2583348.aspx

[33] Song YP, Zhang $P$, Wang $X W$. The significance of the Ldopa induced PC12 cell apoptosis experiment in the mechanism of L-dopa treatment for Parkinson's disease effects fade (wearing-off). J Modern Prevent Med 2013; 40: 737-9. http://www.cnki.net/KCMS/detail/detail.aspx? QueryID $=0 \&$ CurRec $=1 \&$ recid $=$ \& filename $=$ XDYF201304064\& dbname $=$ CJFD2013\&dbcode $=C J F Q \& p r=\& u r l i d=\& y x=\& v=M j Y$ 5NjIxTHV4WVM3RGgxVDNxVHJXTTFGckNVUkwrZIIIUm9G eXpoVkw3TIBTbINhTEc0SDIMTXE0OURZSVI4ZVg

[34] Hu D, Wang N, Zhang ZT, Zhang ZH. Protective effect of curcumin against rotenone-induced toxicity in NGFdifferentiaed PC12 cells. J Stroke and Nervous Dis 2011; 18 : $327-8$.

http://dx.doi.org/10.3969/j.issn.1007-0478.2011.06.002

[35] Zhou JK. The molecular pathways of morphine regulating thioredoxin expression. Master Thesis, Kunming University of Science and Technology, Yunnan, China, 2014:18-57. http://www.cnki.net/KCMS/detail/detail.aspx?QueryID=0\&Cur Rec $=1 \&$ recid=\&filename $=1014353173$. nh\&dbname $=$ CMFD2 $01501 \& \mathrm{dbcode}=\mathrm{CMFD} \& \mathrm{pr}=\& u r l i d=\& \mathrm{yx}=\& \mathrm{v}=\mathrm{MTk} 5 \mathrm{MTJ} \mathrm{GeS} 9 \mathrm{r}$ VTczSVZGMiZHckM5SGRETHJKRWJQSVI4ZVgxTHV4WV M3RGgxVDNxVHJXTTFGckNVUkwrZIIIUm8

[36] Kong SZ. Anti-aging effects of hydroxysaffloryellow A. Doctoral Dissertation, Guangzhou University of Chinese Medicine, Guangdong, China 2014; 8-26. http://d.wanfangdata.com.cn/Thesis_Y2622798.aspx

\section{DOI: http://dx.doi.org/10.6000/1927-3037.2015.04.02.3}

(C) 2015 Wang et al.; Licensee Lifescience Global.

This is an open access article licensed under the terms of the Creative Commons Attribution Non-Commercial License (http://creativecommons.org/licenses/by-nc/3.0/) which permits unrestricted, non-commercial use, distribution and reproduction in any medium, provided the work is properly cited. 